\title{
Behandling ved Statens Institutionsstyrelse i Sverige
}

\author{
Av Jan Beskow
}

I Sverige bedriver Statens institutionsstyrelse, SiS, individuellt anpassad tvångsvård och behandling av ungdomar med allvarliga psykosociala problem samt av vuxna med missbruksproblem. Allvarliga självmordsförsök är vanligt inom SiS och självmord har förekommit. Suicidriskbedömning och akuta suicidpreventiva insatser görs framför allt av psykologer. 
I DESSA SITUATIONER är psykologernas uppgifter att: a) skapa förutsättningar för klientens överlevnad genom suicidriskbedömning och akuta åtgärder, b) skapa den trygghet i relationen som är nödvändig vid behandling av dessa ofta svårt traumatiserade klienter samt c) förse dem med resurser att allt bättre kunna hantera hotfulla situationer.

Vård- och behandlingssituationen inom SiS ställer ofta krav på korta och akuta insatser. Klienterna har inte sällan problem med tillit samt svårigheter att reflektera samt att förstå långsiktiga konsekvenser av sina beteenden. Det finns ofta ett stort behov av att tillsammans med dem arbeta fram konkreta strategier för att hantera svåra situationer.

För psykologerna inom SiS är det en speciellt svår uppgift att hantera självmordsnära klienter. För att utbilda dessa psykologer har SiS under

För psykologerna inom SiS är det en speciellt svår uppgift att hantera självmordsnära klienter. många år anlitat Suicidprevention i Väst, SPIV, en NGOorganisation inom suicidpreventionen med säte i Göteborg. Den här beskrivna samtalsmodellen av Eva da Silva och Lotta Scholander är ett resultat av detta samarbete. Den erbjuder en kombination av suicidriskbedömning, intervention samt arbete med trygghetsskapande och kognitiva modeller.

Av de pojkar, som år 2016 omhändertogs vid SiS behandlingshem för ungdomar, var en tredjedel ensamkommande flyktingar. Vanliga placeringsorsaker var utagerande beteende och våld, siälvskadebeteende, suicidförsök samt missbruk. Att med stor styrka och fara för eget liv söka sig till «lyckolandet Sverige» är en prestation som kräver både begåvning och initiativkraft. Samtidigt är många av dem svårt traumatiserade. I en separat artikeln beskriver Kristin Wahnström bemötande och behandling av en sådan flyktingpojke.

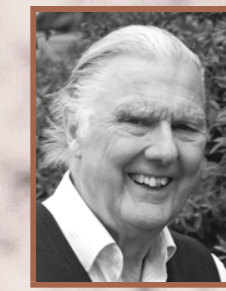

JAN BESKOW är pensionerad professor och psykiater, verksam vid Sahlgrenska Akademin, Göteborgs universitet och vid avdelningen för psykologi vid Linköpings universitet. Jan är sedan många år verksam inom Suicidprevention i Väst, SPIV, i Göteborg och har bl.a. anordnat kurser i suicidprevention på specialistnivå.

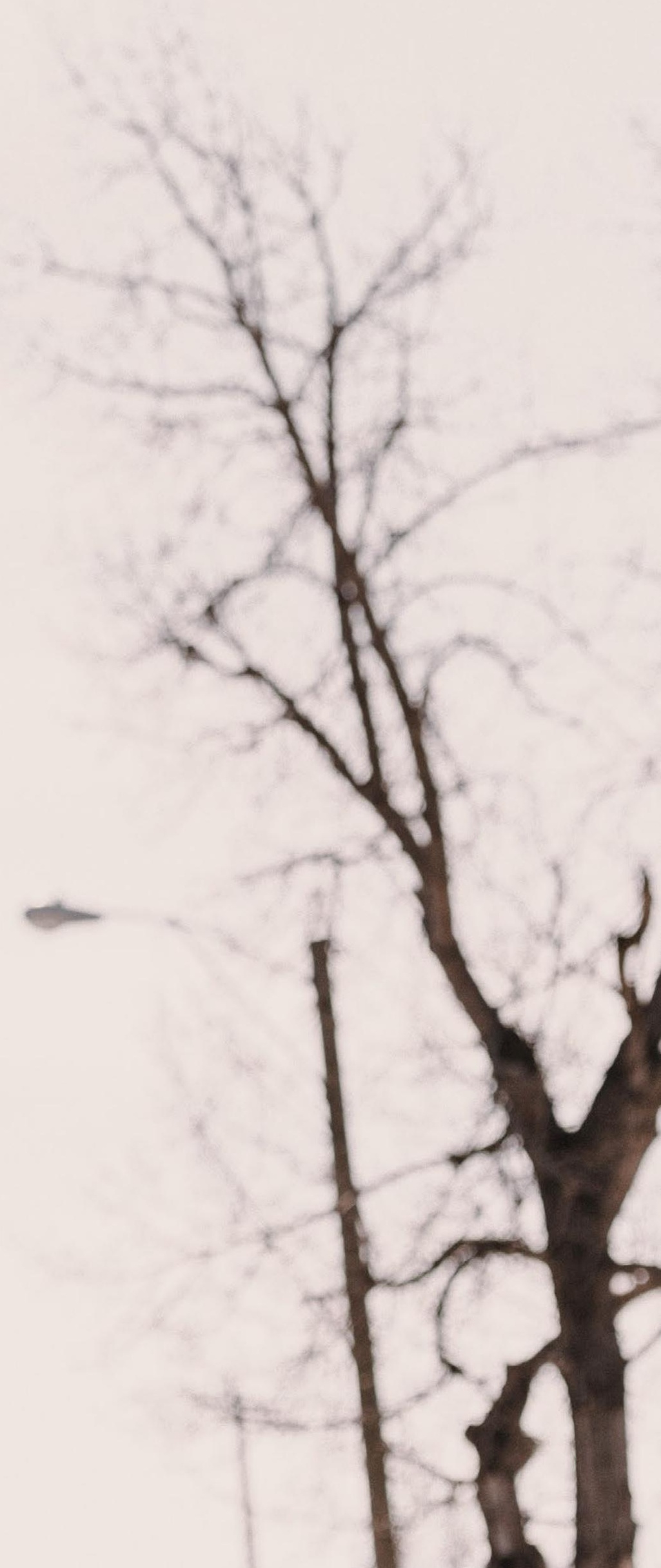

